\title{
INHERITED ANTIGENIC DIFFERENCES IN HUMAN SERUM BETA LIPOPROTEINS. A SECOND ANTISERUM
}

\author{
By B. S. BLUMBERG ANd NANCY M. RIDDELL
}

(From the Geographic Medicine and Genetics Section, National Institutes of Health, Bethesda, Md.)

(Submitted for publication December 10, 1962; accepted February 21, 1963)

The sera of patients who have received multiple transfusions may contain antibodies against normal human serum components $(1,2)$. The first example of such antibodies was reported in a patient (C. de B.) who had received approximately 50 transfusions for the treatment of a refractory anemia of unknown etiology (3). By means of the Ouchterlony double-diffusion technique, it was shown that the antibody formed a precipitin with approximately $55 \%$ of normal U. S. white and Negro sera. By twin, family, and population studies (1), it was shown that the presence or absence of the reacting antigen was under genetic control. Individuals with a "dominant" gene designated $A g^{A}$ in single or double dose (genotypes $A g^{A} / A g^{A}, A g^{A} / A g$ ) were reactors [phenotype $\mathrm{Ag}(\mathrm{a}+)$ ] and those homozygous for the recessive allele $A g$ nonreactors [ $\mathrm{Ag}(\mathrm{a}-)]$. The antigen or antigens that react with the antibodies present in the serum of the frequently transfused patient are serum (low-density) $\beta$-lipoproteins (4). The present paper reports on a second antiserum, the New York antiserum, obtained from a frequently transfused patient with Cooley's anemia. This antiserum reacts with a serum $\beta$ lipoprotein, $\operatorname{Ag}(b+)$, which is antigenically different from the $\mathrm{Ag}(\mathrm{a}+)$ antigen first described, and its inheritance appears to be controlled by a different gene.

\section{MATERIALS AND METHODS}

The gel diffusion precipitation technique (Ouchterlony procedure) was carried out in $5-\mathrm{cm}$ petri dishes, with $0.9 \%$ Oxoid Ionagar ${ }^{1}$ (wt/vol) in $0.7 \mathrm{M}$ sodium phosphate buffer at $\mathrm{pH} 7.4$ by the method described elsewhere (3). All the gels were stained as described below. Many of the gel studies were carried out on lantern slides with small seven-cup Ouchterlony patterns. With a die, six wells $2 \mathrm{~mm}$ in diameter were cut around a center well of the same diameter. The circumference of the central well was $3 \mathrm{~mm}$ from the circumference of the peripheral wells.

\footnotetext{
${ }^{1}$ Consolidated Laboratories, Chicago Heights, Ill.
}

The sera whose reaction types were to be determined were placed in the peripheral wells, and 30 minutes later the transfused patient's serum was placed in the center well. The precipitin reaction was allowed to proceed for up to 48 hours at room temperature, and the plate was then washed in $200 \mathrm{ml}$ of saline (containing a few crystals of sodium azide to inhibit bacterial growth) for 2 days with four changes of saline. The slides were then completely covered with a square of Whatman 1 filter paper and dried at room temperature for 24 to 36 hours. The dried lantern slides were stained with the lipoprotein stain Sudan Black" and with the "general" protein stain Azocarmine ${ }^{2}$ by the method of Uriel and Grabar (5). Agar gel immunoelectrophoresis was done by a modification of the method of Grabar and Williams (6) using standard lantern slide plates with a $6 \mathrm{~mm}$ layer of $1 \%$ Ionagar made up in $0.01 \mathrm{M}$ barbital buffer at $\mathrm{pH}$ 8.4. The lowdensity lipoproteins were separated from the other serum proteins by ultracentrifugation in a high-density salt medium by the method of Havel, Eder, and Bragdon (7). Two fractions were separated, one of a density less than 1.063 (low-density lipoprotein) and the other with a density greater than 1.063 (high-density). The presence of esterase activity was determined by the method of Uriel (8), in which the agar-coated lantern slide is washed and dried as for staining, and covered with a solution containing the esterase substrate $\beta$-naphthol acetate $^{3}$ and the dye Diazo Blue ${ }^{3}$. After exposure to the substrate and dye for 60 minutes, the slide is washed with $2 \%$ acetic acid. The presence of enzyme activity in a precipitin line is indicated by a bright pink stain.

Sera from several populations were used in the study. The U.S. white sera were collected from employees at the National Institutes of Health at the time of their routine pre-employment medical examinations. The U.S. Negro sera were collected in Evans County, Georgia, and are described elsewhere (9). The sera from the Chalkidiki Peninsula in northern Greece were collected during a survey arranged for other purposes (10). They were collected casually, primarily from adults in three villages on the peninsula. The sera from Atalanti, Greece, were collected from male school children (ages 10 to 13 ) at the high school. The Peruvian sera 4 were collected from the Quechua Indians in the villages of

2 National Aniline, New York, N. Y.

3 Nutritional Biochemicals Corp., Cleveland, Ohio.

4 Courtesy of Dr. Marshall T. Newman, U. S. National Museum, Washington, D. C. 
Vicos in the northern sierra, and included many family members. The Sioux Indian sera ${ }^{5}$ were collected from school children at the Holy Rosary Mission School, Pine Ridge, South Dakota. The sera from Rongelap (Marshall Islands) are described elsewhere (11); the samples ${ }^{6}$ used in the present study were collected in 1961 and 1962.

The serum containing the precipitin was found in patient I.M., a 7-year-old girl with Cooley's anemia, both of whose parents were born in Greece and carried the Cooley's trait. The diagnosis was made in the child at age 10 months. She has received blood transfusions approximately monthly since 14 months of age, and at the time the first blood sample was tested for the presence of antibodies, she had received approximately 40 transfusions. She continued to receive transfusions after the discovery of the antibody, with no apparent severe, acute transfusion reaction. ${ }^{7}$

\section{RESULTS}

The serum of I.M. formed a thin, crescentshaped precipitin line (which curved towards the antigen well) with some, but not all sera (Figure 1). The precipitin line was not so intense as that found between the first antiserum described (antiserum C. de B.) and the $\operatorname{Ag}(\mathrm{a}+)$ antigen, but after staining with Sudan Black, it was possible to separate reactors from nonreactors. Individuals who react with the New York antiserum are referred to as $\operatorname{Ag}(\mathrm{b}+)$; those who do not react

${ }^{5}$ Courtesy of Dr. C. J. Witkop and Mr. W. C. Leyshon, National Institutes of Health, Bethesda, Md.

6 Courtesy of Dr. R. A. Conard, Brookhaven National Laboratory, L. I., N. Y.

7 We are greatly indebted to Drs. Marion Erlandson and C. H. Smith of New York Hospital for providing serum specimens from their patient. are $A g(b-)$. The reacting antigen is referred to as the $A g(b+)$ lipoprotein. The radius of curvature of the $C$. de $B$. precipitin line appears to be smaller than that of the New York line.

Stability of antigen. To determine the stability of the antigen that reacted with the New York antiserum, 12 sera were stored at room temperature and tested daily for 1 week, and then every 4 days. The reactions were still positive on day 7 , but became faint on day 11 . Many of the sera were nonreactive after 15 days at room temperature. There was no change in reactivity when the sera were stored at $4^{\circ}$ or at $-20^{\circ} \mathrm{C}$ for 18 days. Rapid freezing and thawing up to fifty times of two freshly drawn sera had no effect on the reactivity. When sera stored frozen for more than 1 year were tested, the reproducibility of the results was decreased. Therefore, tests should be performed on freshly collected serum or plasma, although serum or plasma stored at $-20^{\circ} \mathrm{C}$ for periods up to approximately 1 year can also be used.

Blood samples were withdrawn three times a week for 2 weeks from two volunteers, and at irregular intervals up to a month from one of them. The second volunteer was on a low-calorie diet for 3 weeks and a high-calorie diet for 1 week. One specimen was drawn after meals and the others before breakfast. In all cases the sera reacted with the New York antiserum.

Identification of the antigen as a serum lowdensity $\beta$-lipoprotein. Figure 1 is a photograph of an Ouchterlony experiment in which the pre-

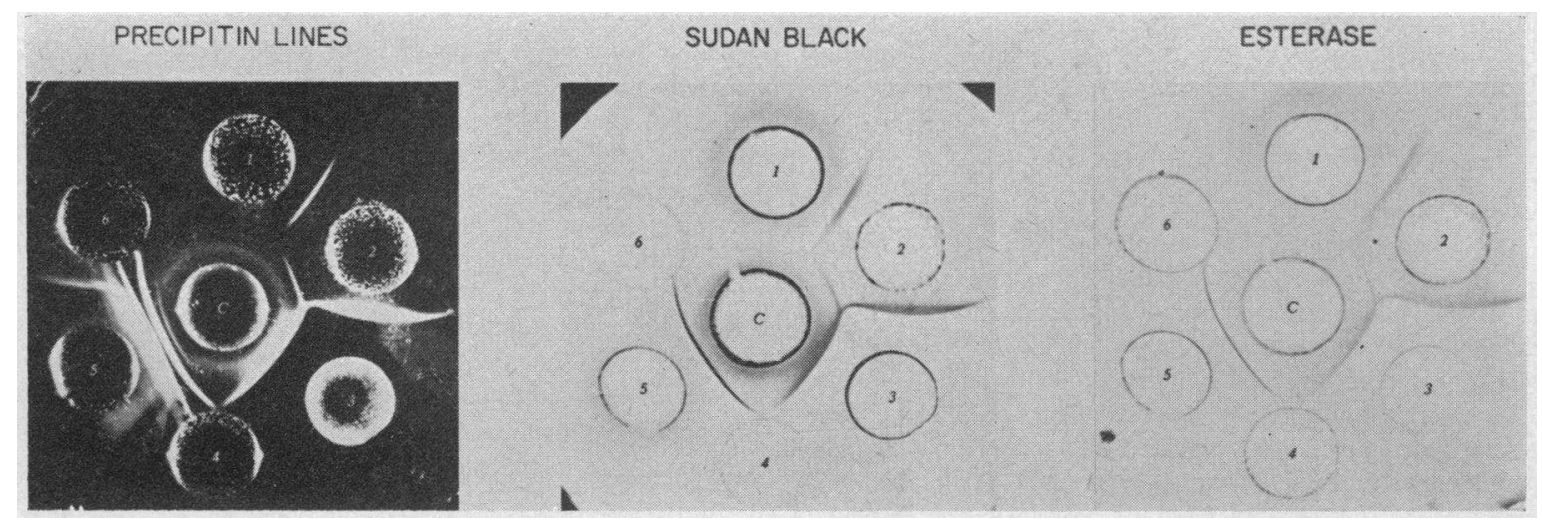

Fig. 1. Photograph of Ouchterlony experiments to Show precipitin lines and staining Reactions. In each case: center well, serum $[\mathrm{Ag}(\mathrm{a}+, \mathrm{b}+)]$ reacting with $\mathrm{C}$. de B. and New York antisera; well 1, New York antiserum; well 2 , C. de B. antiserum; well 3 , rabbit antihuman serum $\beta$-lipoprotein; well 4 , isolated human $\alpha$-macroglobulin; well 5 , monkey antihuman serum; and well 6 , isolated human $\gamma$-globulin. For details, see text. 
cipitin lines were stained with Sudan Black and the "esterase" stain. The center well contains a whole serum that reacts with both C. de B. and New York antisera. The experiment was designed to show that the precipitin lines formed between the New York antiserum (well 1) and the New York antiserum reactor (center well), and between C. de B. (well 2) and the C. de B. reactor (center well) stain with Sudan Black. A positive control was obtained by reacting rabbit antihuman $\beta$-lipoprotein (well 3) against whole human serum (center well). The rabbit antihuman $\beta$-lipoprotein was prepared by immunization of a rabbit with human low-density lipoprotein (density less than 1.063) prepared by the method of Havel, Eder, and Bragdon (7). ${ }^{8}$ The $\beta$-lipoprotein precipitin line between monkey antihuman serum ${ }^{9}$ (well 5) and the center well served as another positive control. Two precipitin lines were used for negative controls, one between monkey antihuman serum (well 5) and isolated human $\alpha$ macroglobulin ${ }^{10}$ that contains no lipoprotein (well 4 ), and another between monkey antihuman serum (well 5) and isolated human $\gamma$-globulin (well 6) that also contains no lipoprotein. Neither of these negative controls stained with Sudan Black.

The precipitin lines formed by New York and C. de B. antiserum, and the positive control precipitin lines all demonstrated esterase activity, whereas the negative control lines did not (Figure 1). As a further control, the esterase experiment was conducted in the same manner, but the $\beta$ naphthol acetate substrate was omitted. No colored precipitin line was detected.

To confirm the identification of the lipoprotein, the low-density $(\beta)$ and high-density $(\alpha)$ lipoproteins of six individual sera and two collections of pooled sera, each with five sera in the pool, were separated by ultracentrifugation. Five of the whole individual sera were reactors, $\mathrm{Ag}(\mathrm{b}+)$. In each of these, the low-density, but not the highdensity portion reacted with New York serum and stained with Sudan Black. One of the individual sera was a nonreactor, $\mathrm{Ag}(\mathrm{b}-)$, and in this, neither of the fractions reacted with New York antiserum. Both of the pooled sera samples

\footnotetext{
8 We are indebted to Dr. Howard Goodman, Bethesda, Md., for providing this antiserum.

9 Immunology, Chicago Ill.

10 Behringwerke, Marburg, Germany.
}

reacted, and in both only the low-density fraction formed a precipitin line with the New York antiserum.

An immunoelectrophoresis experiment was performed to show the reaction between the New York antiserum and whole serum of phenotype $\operatorname{Ag}(a+, b+)$ and to compare it with the reaction between the $C$. de $B$. antiserum and the same whole serum. The antigen migrates in the $\alpha$ globulin position, and no apparent difference in the mobilities of the $\mathrm{Ag}(\mathrm{a}+)$ and $\mathrm{Ag}(\mathrm{b}+)$ antigens was seen. As noted previously (4), the lowdensity lipoprotein migrates as an $\alpha$-globulin in agar gel and as a $\beta$-globulin on paper electrophoresis.

Differences between $A g(a+)$ and $A g(b+)$ lipoproteins. Two experiments were made to determine whether the antigen reacting with the New York antiserum is different from that reacting with the C. de B. antiserum. In Figure 2, the New York antiserum (well 1) reacts with low-density $\beta$-lipoprotein (well 2), the antigen present in the serum of C. de B. (well 3), and whole serum from a subject of phenotype $\mathrm{Ag}(\mathrm{a}+, \mathrm{b}+)$ (well 4). The antibody present in the serum of $C$. de $B$. reacts with the antigen present in the New York serum (well 1) and with the other antigens. All the reactions between
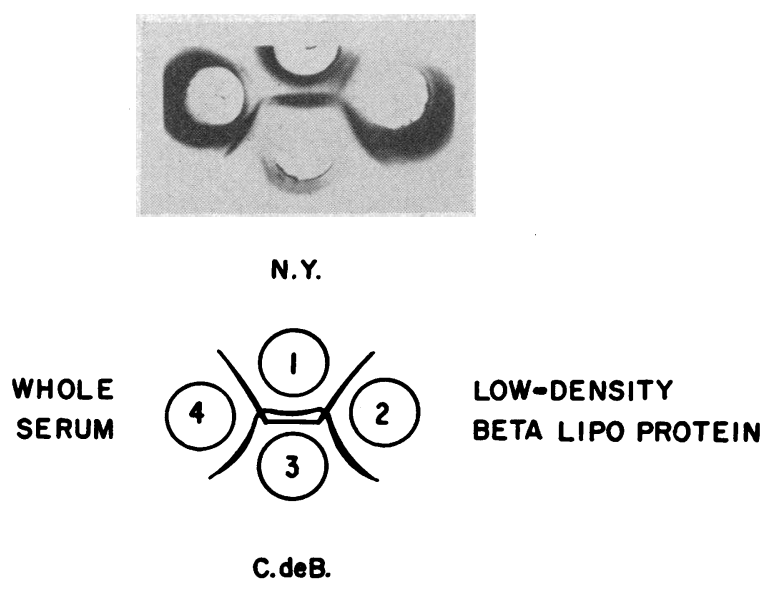

C.deB. and New York Antisera

Fig. 2. Photograph and diagram of OUCh terlony EXPERIMENT TO SHOW THE REACTION BETWEEN NEW YORK (WEll 1) AND C. DE B. (Well 2) ANTISERA AND BETWEEN THE WHOLE SERUM (WELL 4) AND LOW-DENSITY $\beta$-Lipoprotein (Well 3) of A REACtOR. Precipitin lines have been stained with Sudan Black. 

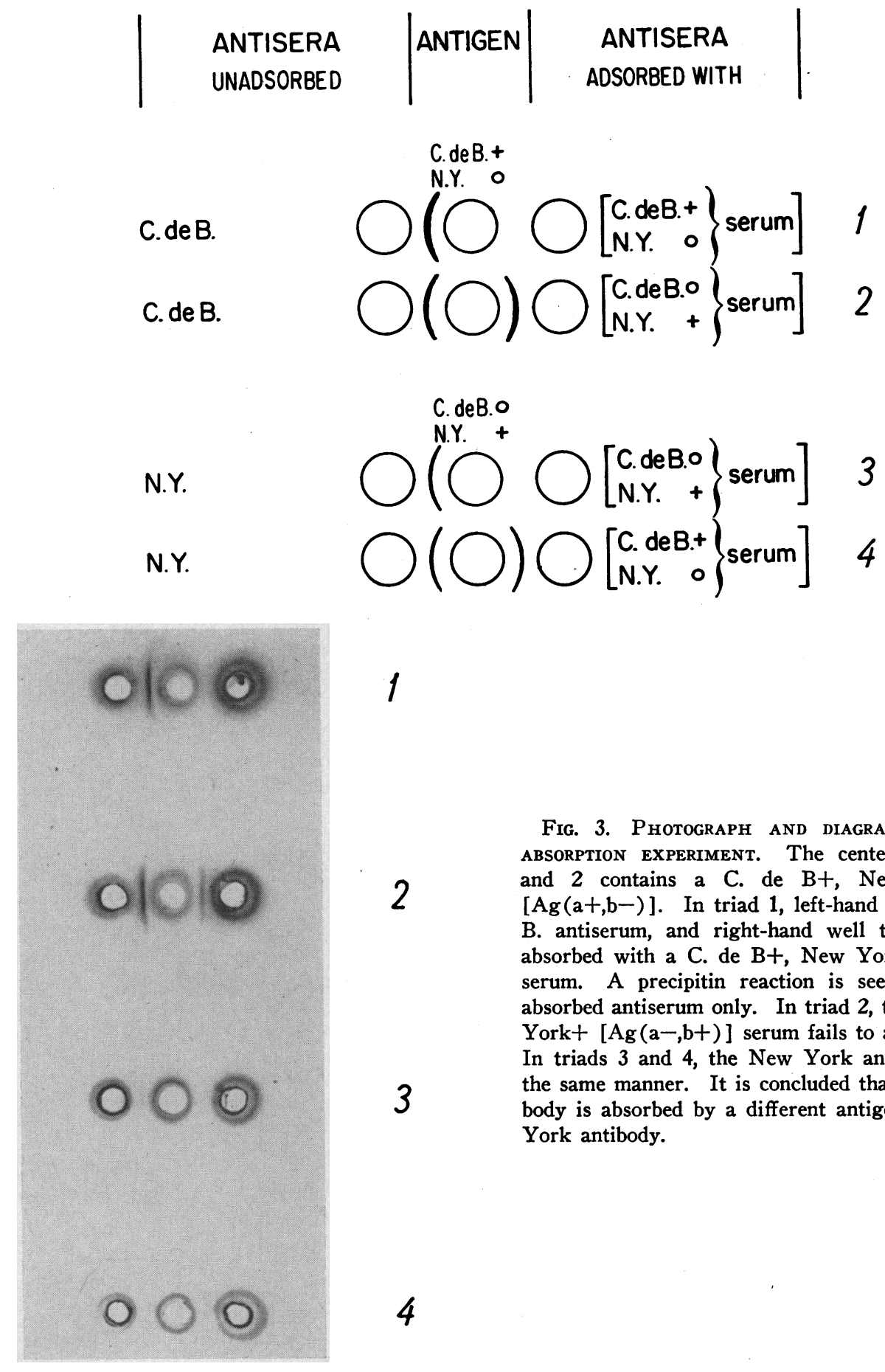

New York antiserum and the antigens show a line of fusion, as do all the reactions between C. de B. antiserum and the antigens. The two sets of lines cross each other, indicating that they are not antigenically identical.

Fig. 3. Photograph and diagram OF INTRA-BASIN ABSORPTION EXPERIMENT. The center well of triads 1 and 2 contains a $\mathrm{C}$. de $\mathrm{B}+$, New York 0 serum [Ag(a+,b-)]. In triad 1, left-hand well contains C. de $B$. antiserum, and right-hand well the same antiserum absorbed with a $\mathrm{C}$. de $\mathrm{B}+$, New York $0[\mathrm{Ag}(\mathrm{a}+, \mathrm{b}-)]$ serum. A precipitin reaction is seen opposite the unabsorbed antiserum only. In triad 2 , the C. de B. 0 , New York+ $[\mathrm{Ag}(\mathrm{a}-\mathrm{b}, \mathrm{b})]$ serum fails to absorb the antibody. In triads 3 and 4 , the New York antiserum is tested in the same manner. It is concluded that the C. de B. antibody is absorbed by a different antigen than is the New York antibody.

In a second experiment, the "intra-basin" absorption method was used (Figure 3). Approximately $10 \mu \mathrm{g}$ of a serum of phenotype $\operatorname{Ag}(\mathrm{a}+, \mathrm{b}-)$ was placed in the right-hand well of triad 1 . Twenty minutes later, the same amount of C. de B. 
antiserum was placed in the cup. $\operatorname{An} \operatorname{Ag}(a+, b-)$ serum was placed in the center well, and undiluted C. de B. antiserum in the left-hand well of triad 1. The $\mathrm{Ag}(\mathrm{a}+, \mathrm{b}-)$ serum absorbed the antibody present in the C. de B. antiserum, and no reaction was seen between the righthand and center wells. The unabsorbed C. de B. antiserum (left-hand well) gave a reaction with the antigen in the serum in the center well. In triad 2, an $\operatorname{Ag}(a-, b+)$ serum failed to $a b-$ sorb the antibody present in C. de B. antiserum, and a reaction was seen on both sides of the center cup. In the second part of the experiment (triads 3 and 4), an $\operatorname{Ag}(a-b+)$ serum absorbed the antibody present in the New York antiserum (triad 3), while an $\operatorname{Ag}(\mathrm{a}+, \mathrm{b}-)$ serum failed to do so (triad 4).

These experiments taken together suggest that the antigens with which C. de B. antiserum and New York antiserum react are both low-density $\beta$-lipoproteins whose electrophoretic mobilities in agar gel are not detectably different. They are, however, antigenically distinct. Furthermore, $\mathrm{Ag}(\mathrm{a}+)$ antigen is present in New York antiserum, and $\mathrm{Ag}(\mathrm{b}+)$ antigen in $\mathrm{C}$. de $\mathrm{B}$. antiserum. Both of these antigen antibody lines possess esterase activity.

Population studies. As noted above, sera stored for a long time lost some ability to form a visible precipitate with New York antiserum. The sera used in the present study had been stored for variable periods up to 1 year. Within each population sample, all the sera had been collected at about the same time and stored under identical conditions. Nevertheless, it is possible that some of the sera classified as nonreactors were in fact $\mathrm{Ag}(\mathrm{b}+)$; the classification of the positive reactors is more certain.

The results of the population studies are shown in Table I. The frequency of the New York antiserum reactors, $\operatorname{Ag}(b+)$, is high in U.S. white and Negro populations, but somewhat lower in American Indians. The Micronesians have the lowest frequencies of the populations studied. Studies of sex distribution in the Micronesians showed that $34 \%$ of 73 males and $33 \%$ of 76 females on whom information was available reacted with the New York antiserum. The age distribution of the Micronesian population varied from about 4 years to older than 70 . There was no
TABLE I

Population studies

\begin{tabular}{|c|c|c|c|c|c|c|}
\hline \multicolumn{2}{|c|}{ Sera studied } & \multirow{3}{*}{$\begin{array}{l}\text { Total } \\
\text { no. }\end{array}$} & \multicolumn{4}{|c|}{ Antisera reactors } \\
\hline \multirow[t]{2}{*}{ Population } & \multirow[t]{2}{*}{ Location } & & \multicolumn{2}{|c|}{ C. de B. } & \multicolumn{2}{|c|}{ New York } \\
\hline & & & no. & $\%$ & no. & $\%$ \\
\hline U. S. white & Maryland & 120 & 71 & 59.2 & 116 & 96.7 \\
\hline U. S. Negro & Georgia & 149 & 101 & 67.8 & 148 & 99.3 \\
\hline Greek & Chalkidiki & 103 & 73 & 70.9 & 92 & 89.3 \\
\hline Greek & Atalanti & 100 & 73 & 73.0 & 97 & 97.0 \\
\hline Quechua Indian & Peru & 102 & 71 & 69.6 & 88 & 86.3 \\
\hline Sioux Indian & S. Dakota & 143 & 130 & 90.9 & 111 & 77.6 \\
\hline Micronesian & $\begin{array}{c}\text { Rongelap Atoll, } \\
\text { Marshall Is. }\end{array}$ & 189 & 186 & 98.4 & 82 & 43.4 \\
\hline
\end{tabular}

heterogeneity for age, but results from the small numbers studied cannot rule out age variation.

The frequency of $\mathrm{C}$. de $\mathrm{B}$. antiserum reactors is higher than previously reported in U.S. population (1), probably owing to the increased sensitivity resulting from staining with Sudan Black. Staining of the precipitin lines also revealed that there is more than one kind of $\mathrm{Ag}(\mathrm{a}+)$ reaction. Evidence to be presented elsewhere indicates that the C. de B. antiserum contains more than one antibody. All varieties of $\mathrm{C}$. de $\mathrm{B}$. reactors are indicated as $\mathrm{Ag}(\mathrm{a}+)$.

Genetic studies. Since $\mathrm{Ag}(\mathrm{b}-)$ sera are very rare in U.S. white and Negro populations, it is difficult to find segregating families. Forty-six families consisting of both parents and one or more children were studied, but these did not contribute significantly to the genetic analysis. All the matings were $A g(b+) \times A g(b+)$, and with the exception of one family where one of two children was $\operatorname{Ag}(b-)$, all the offspring were $\operatorname{Ag}(b+)$.

In the Micronesians, however, the frequency of reactors and nonreactors is about equal. Sera were available from fourteen families consisting of both parents and at least one child, and the results of the studies on these are shown in Figure 4. There were ten families in which at least one parent was a reactor (R-12, R-15, R-25, R-26, $\mathrm{R}-27, \mathrm{R}-28, \mathrm{R}-31, \mathrm{R}-35, \mathrm{R}-46$, and $\mathrm{R}-47$ ) ; in these, offspring were either reactors or nonreactors. In four of the families (R-18, R-34, $\mathrm{R}-37$, and R-38), both parents and all offspring were nonreactors. The observed segregation is consistent with the hypothesis that the presence of the reacting antigen is determined by a single, autosomal gene pair. Individuals homozygous or heterozygous for a gene tentatively designated 


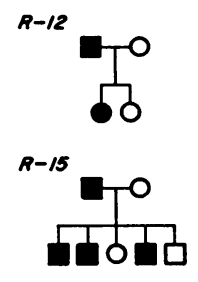

$R-18$<smiles>CCC1(O)CC1</smiles>
口冋

$R-25$
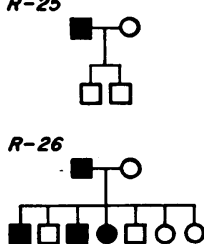

$R-27$

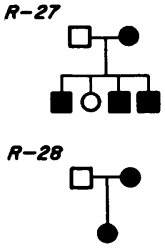

$\boldsymbol{R}-\mathbf{3 1}$

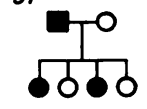

$R-34$

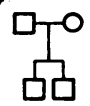

$R-35$

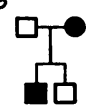

$R-37$

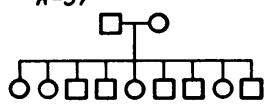

$R-38$
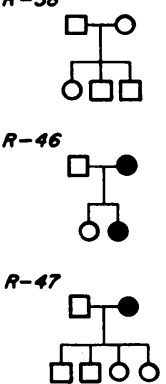

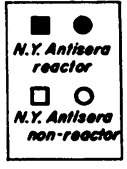

ion-reacter

Fig. 4. A STUdy of FOURTEen Micronesian FaMilies With the New YoRk antiserum. In ten (R-12, R-15, R-25, R-26, R-27, R-28, R-31, R-35, R-46, and R-47), at least one parent was a reactor, and offspring were either reactors or nonreactors. In four ( $\mathrm{R}-18, \mathrm{R}-34, \mathrm{R}-37$, and R-38), both parents were nonreactors, as were all the offspring. The males are symbolized by squares and the females by circles.

$A g^{B}$ react with the New York antiserum. Those homozygous for its allele do not react. If this hypothesis is correct, then the offspring of $\mathrm{Ag}(\mathrm{b}+) \times \mathrm{Ag}(\mathrm{b}+)$ or $\mathrm{Ag}(\mathrm{b}+) \times \mathrm{Ag}(\mathrm{b}-)$ matings may be either $A g(b+)$ or $A g(b-)$, and all offspring of $A g(b-) \times A g(b-)$ matings should be $A g(b-)$ (Figure 4).

Eleven identical and five nonidentical twin pairs (U.S. whites and Negroes) were studied. Since all the sera were New York antiserum reactors, this finding does not contribute significantly to the genetic information.

The relation between the reactions of the New York antiserum, the C. de B. antiserum, and other antisera will be described elsewhere.

Mother-child studies. Studies on the presence of $\mathrm{Ag}(\mathrm{a}+)$ material in the sera of mothers at term and in those of their newborn children were previously presented (1). The data were con-

sistent with the hypothesis that the $\operatorname{Ag}(\mathrm{a}+)$ protein is not always present at birth, but is produced sometime later. Also, in some cases the maternal reacting material may be transmitted through the placenta. The present paper gives the data on the $\mathrm{Ag}(\mathrm{b}+)$ phenotypes of mother-child pairs. Sera from 37 mothers taken at term were available for study. The umbilical cord serum of 25 of their infants and heel blood withdrawn 1 to 3 days after birth of the remaining 12 infants were typed with the New York antiserum (Table IIA). If the product of the gene is present at birth and if random mating occurs (hypothesis 1 ), the expected frequency of the four possible mother-child combinations can be roughly estimated by assuming that the genetic hypothesis tentatively advanced for the inheritance of $\mathrm{Ag}(\mathrm{b}+)$ lipoprotein is correct.

The Hardy-Weinberg Law states that $p^{2}+2 p q$ $+q^{2}=1$ in a panmictic population at equilibrium where $p$ is the frequency of a gene at a locus, and

TABLE II

Mother-child studies

A. New York antisera reactor phenotype

\begin{tabular}{|c|c|c|c|c|}
\hline \multirow[b]{4}{*}{ Mother } & \multirow[b]{4}{*}{ Child } & \multicolumn{3}{|c|}{ Number of pairs } \\
\hline & & \multirow[b]{3}{*}{ Observed } & \multicolumn{2}{|c|}{ Expected at birth by } \\
\hline & & & Hypoth & Hypothesis \\
\hline & & & $1 *$ & $2 \dagger$ \\
\hline+ & + & 21 & 31.9 & \\
\hline+ & 0 & 13 & 2.1 & 34 \\
\hline 0 & + & 0 & 2.2 & 0 \\
\hline 0 & 0 & 3 & 0.8 & 3 \\
\hline
\end{tabular}

B. Serial studies of New York antisera reactor phenotypes

\begin{tabular}{rccccc} 
No. & $\begin{array}{c}\text { Mother } \\
\text { at term }\end{array}$ & Birth & $\begin{array}{c}40 \text { to } 60 \\
\text { days }\end{array}$ & $\begin{array}{c}3 \\
\text { months }\end{array}$ & $\begin{array}{c}2 \\
\text { years }\end{array}$ \\
\hline 5 & + & 0 & + & + & \\
6 & + & + & + & & \\
8 & + & + & + & + & \\
9 & + & + & + & & + \\
10 & + & + & & & + \\
11 & + & 0 & & & + \\
12 & + & 0 & & & + \\
13 & + & 0 & & & + \\
14 & + & + & & & + \\
16 & + & 0 & & & + \\
17 & + & + & & & + \\
18 & + & + & & & + \\
19 & + & + & & & + \\
20 & + & + & & & + \\
21 & + & 0 & & & + \\
22 & + & 0 & & &
\end{tabular}

* Product of gene present at birth (random mating).

$\dagger$ Product of gene not present at birth, but appearing later, $\mathrm{Ag}(\mathrm{b}+)$ may be transmitted transplacentally. 
$q$, or $1-p$, is the frequency of its allele. Let $q$ be the frequency of the recessive allele of $A g^{B}$. The frequency $q^{2}$ of the recessive phenotype in the mothers is $3 / 37=0.081$, from which $q=0.28$ and $p=0.72$. (Using the frequencies from a larger population did not appreciably alter the conclusions). From this, the expected heterozygote frequency is $2 p q=0.40$, and the homozygous dominant frequency is $p^{2}=0.52$. With this information, the expected mother-child combinations can be computed, assuming hypothesis 1 (Table IIA).

Among the $\mathrm{Ag}(\mathrm{b}+)$ mothers, a proportion $p^{2} /\left(p^{2}+2 p q\right)$ will be homozygous, and a proportion $2 p q /\left(p^{2}+2 p q\right)$ will be heterozygous. The probability of mating with a father of a particular genotype is proportional to the frequency of that genotype in the population. Of all the possible matings, only two, the female heterozygote times the male heterozygote and the female heterozygote times the male recessive homozygote, can produce negative children. From these probabilities, the expected number of negative offspring among the 34 from positive mothers was computed to be 2.1 , and the positive offspring, $34-2.1$ $=31.9$.

The probability of a negative mother producing a positive offspring is equal to the frequency of the $A g^{B}$ allele (0.72), since the mother contributes only the recessive allele, and the father contributes positive alleles in proportion to the $A g^{B}$ frequency in the population. The expected number of positive offspring is $3 \times 0.72=2.2$ and of negative offspring, $3-2.2=0.8$.

There is a gross discrepancy from the expected numbers (Table IIA), which is unlikely to be due to the inaccuracies introduced by the gene frequency estimates. None of the negative mothers had positive offspring, and far too many of the positive mothers had negative offspring. The data, however, are consistent with a second hypothesis, namely, that the product of the gene is not usually present at birth, but appears sometime later. If this is true, then many of the children who were negative at birth would become positive later. Sera drawn at different times after birth were available from some of the infants, and their reactions with the New York antiserum are shown in Table IIB. All the nonreactors became reactors; the earliest time of conversion recorded was 49 days (no. 5 ).
If the second hypothesis is correct, then an explanation is needed for the presence of the $\mathrm{Ag}(\mathrm{b}+)$ antigen in the sera of some of the newborn children. If $\mathrm{Ag}(\mathrm{b}+)$ specificity is sometimes transmitted transplacentally, then the blood of the newborn offspring of the $\mathrm{Ag}(\mathrm{b}+)$ mothers could be $A g(b+)$ or $A g(b-)$, depending on whether the material is or is not transmitted, but the blood of the newborn offspring of $\mathrm{Ag}(\mathrm{b}-)$ mothers would never be $\mathrm{Ag}(\mathrm{b}+)$. The observations are consistent with this explanation (Table IIA).

There were 33 pairs of sera typed with both the C. de B. and New York antisera. There were instances where $\mathrm{Ag}(\mathrm{a}+, \mathrm{b}+)$ mothers had $\mathrm{Ag}(\mathrm{a}-\mathrm{b}+)$ children, but no instances where $\operatorname{Ag}(a+, b+)$ mothers had $\operatorname{Ag}(a+, b-)$ children. If the finding of $\mathrm{Ag}(\mathrm{a}+)$ and $\mathrm{Ag}(\mathrm{b}+)$ antigenic determinants in cord blood is due to placental transmission rather than to actual production by the fetus (and this can be conclusively proved only by direct transmission experiments), the $\mathrm{Ag}(\mathrm{b}+)$ specificity would seem to be more readily transmitted through the placenta.

\section{DISCUSSION}

The use of human antihuman serum antisera has permitted the distinction of antigenically different $\beta$-lipoproteins. Lipoprotein $\mathrm{Ag}(\mathrm{a}+)$ reacts with the C. de B. antisera, and lipoprotein $\mathrm{Ag}(\mathrm{b}+)$ reacts with New York antisera. Patient C. de B. has lipoprotein $\operatorname{Ag}(\mathrm{b}+)$, but not $\operatorname{Ag}(\mathrm{a}+)$, and conversely, patient I.M. has lipoprotein $\mathrm{Ag}(\mathrm{a}+)$, but not $\mathrm{Ag}(\mathrm{b}+)$. Presumably, the patients each developed an antibody as a consequence of repeated transfusions, the patient's particular inherited lipoprotein determining the antibody that could develop (12).

More than 20 human antihuman serum protein antisera have now been found. There is evidence that there are at least seven different specificities on the $\beta$-lipoproteins that can be detected with these antisera. Nearly all the precipitating antibodies so far described appear to be directed against lipoproteins. This suggests that the lipoproteins are the most antigenic of the human serum proteins, at least as detected by the gel diffusion precipitin method.

It is still not clear why all frequently trans- 
fused patients with the appropriate $\beta$-lipoproteins do not develop antibodies. It is, of course, possible that the phenotypes of the patients who develop antibodies have been altered by repeated transfusions and that the patients have been rendered "autoimmune," that is, have developed an antibody against a serum protein that previously was native. Studies are currently in progress to determine whether such a transformation can occur.

Lawrence, Melnick, and Weimer $(13,14)$ have demonstrated that the $\beta$-lipoproteins possess multiple enzymatic activities in addition to the esterase activity first described by Uriel (8), and have suggested that this may be due to the binding function of the lipoprotein. The particular $\beta$ lipoproteins that react with $\mathrm{C}$. de B. and New York antisera both have esterase activity.

The family studies, at least in the population studied, are consistent with the hypothesis that the presence of the reacting antigen $\mathrm{Ag}(\mathrm{b}+)$ is determined by a single autosomal gene pair. Individuals homozygous or heterozygous for a gene tentatively designated $A g^{B}$ react with the New York antiserum. Those homozygous for its allele do not react. This hypothesis will require further confirmation, which may be obtained when additional families from appropriate populations are studied. These may also help to define the genetic relationship between the $A g(a+), A g(b+)$, and other lipoprotein variants.

The simplest interpretation of the mother-child studies is that in many cases the lipoprotein gene product does not appear until sometime after birth. This would prevent the development of antibodies in mothers whose phenotypes were different from those of their offspring. If the maternal specificity can pass the placental barrier, as the data suggests, then it would be interesting to determine if children exposed to the antigen in utero react differently from children who are not so exposed when challenged with $\beta$-lipoprotein by transfusion or other means later in life.

\section{SUM MARY}

1. A second antiserum (New York antiserum) is described that reacts with a low-density $\beta$-lipoprotein present in the serum of some normal persons, but not others.

2. The lipoprotein with which New York anti- serum reacts $[\mathrm{Ag}(\mathrm{b}+)$ protein] is antigenically different from that with which the first discovered antiserum (C. de B. antiserum) reacts $[\mathrm{Ag}(\mathrm{a}+)$ protein]. No difference in electrophoretic mobility between the two was detected.

3. Preliminary family studies in a Micronesian population indicate that the presence of the $\mathrm{Ag}(\mathrm{b}+)$ lipoprotein is inherited as a simple, autosomal, dominant trait.

4. Mother-child studies are consistent with the hypothesis that the $\mathrm{Ag}(\mathrm{b}+)$ material is not produced at birth, but sometime later. In some cases, the maternal $\mathrm{Ag}(\mathrm{b}+)$ specificity may pass the placental barrier and enter the circulation of the fetus.

5. The antigen-antibody precipitin line has esterase activity.

\section{REFERENCES}

1. Blumberg, B. S., A. D. Bernanke, and A. C. Allison. A human lipoprotein polymorphism. J. clin. Invest. 1962, 41, 1936.

2. Blumberg, B. S., and A. C. Allison. Studies on the isoprecipitin determined human serum polymorphism. Proc. 2nd int. Conf. hum. Genet., Rome, Sept., 1961.

3. Allison, A. C., and B. S. Blumberg. An isoprecipitation reaction distinguishing human serum-protein types. Lancet 1961, 1, 634.

4. Blumberg, B. S., S. Dray, and J. C. Robinson. Antigen polymorphism of a low-density beta-lipoprotein. Allotypy in human serum. Nature (Lond.) 1962, 194, 656.

5. Uriel, J., and P. Grabar. Emploi de colorants dans l'analyse électrophorétique et immuno-électrophorétique en milieu gélifié. Ann. Inst. Pasteur 1956, $90,427$.

6. Grabar, P., and C. A. Williams, Jr. Méthode immuno-électrophorétique d'analyse de mélanges de substances antigéniques. Biochim biophys. Acta (Amst.) 1955, 17, 67.

7. Havel, R. J., H. A. Eder, and J. H. Bragdon. The distribution and chemcial composition of ultracentrifugally separated lipoproteins in human serum. J. clin. Invest. 1955, 34, 1345.

8. Uriel, J. Caractérisation des cholinestérases et d'autres estérases carboxyliques après électrophorèse et immunoeléctrophorèse en gélose. I. Application à l'étude des estérases du sérum humain normal. Ann. Inst. Pasteur 1961, 101, 104.

9. McDonough, J. R., C. G. Hames, B. G. Greenberg, L. H. Griffin, Jr., and A. J. Edwards, Jr. Observations on serum cholesterol levels in the twin population of Evans County, Georgia. Circulation 1963. In press. 
10. Barnicot, N. A., A. C. Allison, B. S. Blumberg, G. Deliyannis, A. C. Krimbas, and A. Mpallas. Genetics of Greek populations. I. Haemoglobin types. Ann. hum. Genet. 1963, 26, 229.

11. Blumberg, B. S., and Zora Gentile. Haptoglobins and transferrins of two tropical populations. Nature (Lond.) 1961, 189, 897.

12. Cinader, B. Specificity and inheritance of antibody response: a possible steering mechanism. Nature (Lond.) 1960, 188, 619.
13. Lawrence, S. H., and P. J. Melnick. Enzymatic activity related to human serum beta-lipoprotein: histochemical, immuno-electrophoretic and quantitative studies. Proc. Soc. exp. Biol. (N. Y.) 1961, 107, 998.

14. Lawrence, S. H., P. J. Melnick, and H. E. Weimer. A species comparison of serum proteins and enzymes by starch gel electrophoresis. Proc. Soc. exp. Biol. (N. Y.) 1960, 105, 572. 